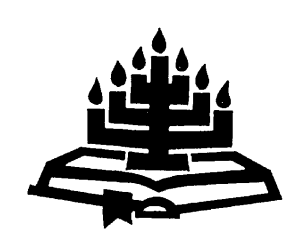

\title{
'n Noodkreet om God se regverdiging of 'n wraakroep om selfgelding? Martelaars aan die voet van die altaar (Op. 6:9-11)
}

\author{
J.A. du Rand \\ Buitengewone Professor: Fakulteit Teologie \\ Potchefstroomkampus \\ Noordwes-Universiteit \\ POTCHEFSTROOM \\ E-pos: jdurand@uj.ac.za \\ jdrth@yahoo.com
}

\begin{abstract}
A cry of distress for justice or a vindictive call for vengeance? The martyrs under the altar (Rev. 6:9-11)

The essential question to be answered in this article arises from the martyrs' cry in Revelation 6:9-11. Is the cry to be interpreted as a justification of God's judgement or as a cry for vengeance by the suffering martyrs? In other words, is it about God's disposition in the history of Christianity or about the revengeful self-satisfaction of the martyrs? Both these views have been proposed by exegetes and this has led to confusing theological viewpoints. These exegetical preferences determine further dogmatic and ethical implications. The question may also be asked whether it is at all fitting for Christians to urge God to take revenge on their fellows. In almost all the commentaries on Revelation 6:9-11 the exegetes have neglected the theological implications of their exegetical choices concerning these texts. Newer research on the psychological and socio-cultural situation of the first historical receivers of Revelation, as well as the issue of martyrdom in the early church, help an exegete to gain new insights into an old exegetical problem. Decisive exegetical results also serve as key motifs in the unfolding of the dramatic narrative and theological message in the further chapters of Revelation.
\end{abstract}




\section{Opsomming}

\section{'n Noodkreet om God se regverdiging of 'n wraakroep om selfgelding? Martelaars aan die voet van die altaar (Op. 6:9-11)}

Die wesenlike vraag wat in hierdie artikel aan die orde kom, is of die martelaars se noodroep in Openbaring 6:9-11 fokus op die regverdiging van God se oordeel of op die martelaars se selfsugtige wraak. Handel dit dus oor die goddelike beskikking in die gang van die geskiedenis van die Christendom of oor die martelaars se wraakgierige selfbevrediging? Albei standpunte het deur die eeue eksegetiese steun gekry wat weer gelei het tot uiteenlopende en dikwels verwarrende teologiese standpunte. Die eksegetiese keuses het onvermydelik dogmatiese en etiese implikasies. Dit kan verder gevra word of dit teologies betaamlik is dat mense by God kan smeek om wraak te neem op medeskepsels van God. Bogenoemde eksegetiese kernvraag met sy teologiese implikasies word gerieflikheidshalwe in die meeste eksegetiese analises van Openbaring 6:9-11 verswyg. Nuwer navorsing oor die psigologiese en sosio-kulturele situasie van die historiese eerste ontvangers van Openbaring, asook oor martelaarskap in die vroeë kerk, word in hierdie artikel aangewend om 'n nuwe blik te kry op 'n ou eksegetiese probleem. Eksegetiese uitsluitsel word oor genoemde vrae na aanleiding van Openbaring 6:9-11 verkry en die resultaat ontplooi as 'n sleutelmotief en "sakelys" in die ontvouing van die dramatiese narratief en teologiese boodskap in die res van die gang van die dramatiese narratief van Openbaring.

\section{Vraagstelling en doel}

Heil (1993:221) behandel Openbaring 6:9-11 eksegeties en ken aan hierdie gedeelte 'n sleutelrol toe in die ontplooiing en gang van die boek Openbaring as 'n geheel. Sonder om die stand van navorsing wat volledig deur Heil (1993:221-227) en Pattemore (2003:7-38) behandel word te herhaal, kan aanvaar word dat oor genoemde verse reeds hewige debat gevoer is (Casey, 1981:7-24). Dit is opvallend dat die debatteerders nie noodwendig dieselfde vrae vra nie. Beale (1999:389-394) laat byvoorbeeld die klem val op die ko-teks van Openbaring 6:9-11 en verklaar die martelaars se roep as die uitvloeisel van die vier perde-seëls. Boring (1986:259, voetnoot 5 \& 6) verreken Collins (1977:241-256) se eensydige klem op die politieke en sosiale betekenis van die martelaars se roep en bring die gesprek terug binne die raamwerk en rol van die enger teologie. Aune (1998:403-405) weer, lei die debat dieper in die mitologiese kosmologie in en fokus eerder op die moontlike ontstaanswêreld van 
die betrokke verse en gebeure (Aune, 1996:271-272). Om na die teologiese betekenis van die martelaars se roep te vra, fokus dus op nuwe vrae vanuit nuwer hoeke van die betrokke teksgedeelte.

Openbaring 6:9-11 beskryf die vyfde seël wat oor die smeekroep van die martelaars aan die voet van die altaar handel. Die raamwerk waarbinne die roep van die martelaars klink, is dus 'n vraag na God se voorsienigheid, met klem op die appèl op sy regverdige oordeel. Daarteenoor staan die brandende moontlikheid van die martelaars se persoonlike wroeging wat uiting vind in 'n roep om vergelding van hulle vyande, met inagneming van die knellende heersende krisisomstandighede. Hierdie vraag verdiep wanneer 'n eksegeet moet vra of dit 'n Christen betaam om God te vra om wraak te neem op wie ook al die gelowiges benadeel en vervolg.

Neweskikkende vrae wat ook na vore tree is: Moet die vyfde seël letterlik of simbolies verstaan word? Is alle gelowiges daaraan uitgelewer om as martelaars te sterf? Wat is die identiteit van die siele aan die voet van die altaar? 'n Minder belangrike saak wentel om die vraag van watter altaar hier ter sprake is, 'n brandofferaltaar of 'n reukofferaltaar? Ook die vraag na die verband tussen die vyfde seël en die res van die boodskap van Openbaring kom aan die orde (Bauckham, 1993a:78; 1993b:17).

Die doel is om met behulp van eksegetiese analise die teologiese inhoud en sosiale trefkrag van die vyfde seël te ontleed om tot teologiese helderheid te kom oor die wesenlike betekenis van die martelaars se roep.'n Gemotiveerde eksegetiese neerslag van 'n ontleding van Openbaring 6:9-11 kan ook in die interpretasie van die res van die ontplooiing van die narratief van gebeure in Openbaring ' $n$ bepaalde hermeneutiese rol speel.

\section{Ko-teks en konteks}

Ko-teks verwys na die teksverband waarin Openbaring 6:9-11 staan en konteks betrek die kultuurhistoriese en sosiale teksverbande. Die navorsingsoorsig van Heil (1993:221-224) in hierdie verband bevestig die bydraende betekenis van die invloed van die sosio-wetenskaplike navorsing op die literêre eksegese van Openbaring.

Die direkte semantiese teksverband (ko-teks) wat veral fokus op die geloofstryd van die navolgers van die Lam gedurende die eindtyd, strek vanaf Openbaring 5. Volgens Openbaring 5:9 en 10 word God geloof omdat Hy mense vir Hom "vrygekoop het uit elke stam en taal en volk en nasie". Hierdie verlostes is bestem om as priesters vir 
God en as sy konings op aarde te leef (Op. 5:10). Die opvallende volgens Openbaring 5:8 is dat elkeen van die ouderlinge en lewende wesens "'n goue bak vol wierook, dit is die gebede van die gelowiges", vashou. Dit beklemtoon die skakeling tussen hemel en aarde en word weer in Openbaring 6:9-11 op die spits gedryf. Ons sou dit kommunikasie in lyding en vervolging kon noem, 'n tema wat van die begin van die vertelling af prominensie geniet (vgl. Op. 1:9; 2:911,$13 ; 3: 8$ ). Die bedoeling van hierdie teologiese tema van lyding het grotendeels te doen met die gelowiges se identifikasie met die offergawe van die Lam, Jesus Christus. Die Christusgebeure plaas martelaarskap in 'n Christologiese raamwerk. Dit is 'n belangrike onderliggende grondslag in die verdere navorsingsondersoek na Openbaring 6:9-11.

Die eerste vier seëls (Op. 6:9-11) wat oopgebreek word, berig oor die vier gekleurde perde en hulle ruiters wat as 'n eenheid van oordeel die wêreld tref (vgl. Pattemore, 2003:124 e.v.; Heil, 1993:222). Beale (1999:372-74) beklemtoon die agtergrond uit Sagaria 1:7-17 en 6:1-8 in die vertelling van die eerste vier seëls (Osborne, 2003:269-276). Tereg kan gevra word wat die verband sou kon wees tussen Sagaria 1 en 6 met Openbaring 6:9-11 via Openbaring 6:1-8. Volgens die teksverband van Sagaria tree die ruiters van die strydwaens as agente van God op met die opdrag om die nasies te straf oor hulle optrede teen Jerusalem en Juda (vgl. Beale, 1999: 372 ). Die eerste vier seëls het beslis ook ten doel om die aardbewoners te straf.

Alhoewel daar in Openbaring 6:1-8 sprake is van die aardbewoners (Op. 6:4, 8) of ongelowiges moet die herhaling van sleutelbegrippe

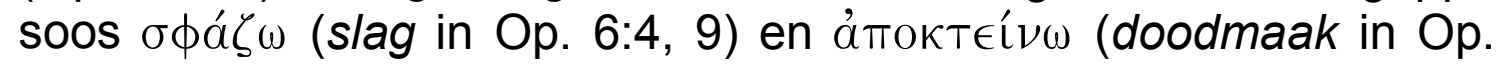
$6: 8,11)$ nie misgekyk word nie. Op grond van die slagting van die Lam (Op. 5:9) loop God se oordeel uit op die slagting en doodmaak van die goddeloses (Op. 6:4, 8) en weet die gelowiges dat hulle slagting en om doodgemaak te word, deel is van hulle identifikasie met die Lam, deur vervolging wat op slagting en doodmaak kan uitloop (Op. 6:9, 11).

Die verband tussen die eerste vier seëls en die vyfde word weereens bevestig in die daaropvolgende Openbaring 7:13-16 waar sprake is van "die groot verdrukking" en die gelowiges wat "wit klere" aan het, "wit gewas in die bloed van die Lam" (vgl. Op. 6:11 met 7:14 en 6:9 met 7:14). Openbaring 6:9-11 pas dus goed in by die tipiese teologiese lyn van die Lam wat geslag is en verlossing bring; hulle wat die verlossing verwerp en onder die oordeel val, maar ook hulle wat vrygekoop is en ter wille van hulle getuienis moet ly en 
(soms) doodgemaak word (vgl ook Henog 47:4 en 4 Esra 4:35-37; Aune, 1998:391; en Black, 1985:49).

Die historiese bydrae tot 'n kontekstuele denkwêreld van vervolging en martelaarskap het hoofsaaklik gekom van keiser Domitianus se edik in die vroeg-negentigerjare. Dit het die aanplant van die wingerde in die provinsies verbied met die motivering dat daar eerder graan verbou moes word. Ekonomiese en sosiale vervolging, veral in die provinsies, het algemeen voorgekom (vgl. Thompson, 1990: 174; Du Rand, 1990:199 e.v.). Die apokaliptiese retoriek in Openbaring 6:9-11 het 'n psigologiese effek en sosiale funksie omdat die leser deur 'n betrokkenheid by die teks die alledaagse krisissituasie verwerk en dit in die raamwerk van die lydende en geslagte Lam verstaan. Teologiese singewing bring psigologiese katarsis en dit hou ook direkte betekenis in vir die sosiale situasie (vgl. Malina, 1995:17-19; Thompson, 1986:149-156; Prigent, 1988:270-277).

Johannes se verbanning na Patmos (Op. 1:9) en Antipas se dood in Pergamum (Op. 2:13) gee blyke van werklike vervolging van Christene. Sporadiese intimidasie en keiserverering het van tyd tot tyd Christelike martelaars opgelewer (vgl. Aune, 1998:403; Du Rand, 1990:204 e.v.; Musvosvi, 1993:187).

Kontekstueel en ko-tekstueel blyk dit dat martelaarskap aan die einde van die eerste eeu n.C. direk verband hou met Openbaring se apokaliptiese teologie, die betrokke krisissituasie in Klein-Asië en die projeksie van 'n simboliese universum waarvolgens God op die troon sit en die martelaars navolgers van die Lam is (Satake, 1991:308-314).

\section{Opbou van Openbaring 6:9-11}

Met die oog op die verdere analise van die navorsingsvrae en die soeke na antwoorde is ' $n$ gedagteanalise van die Grieks in Openbaring 6:9-11 gedoen met die klem op die denkinhoude. In vertaalde vorm ontplooi dit soos volg: 
1. Situering (6:9)

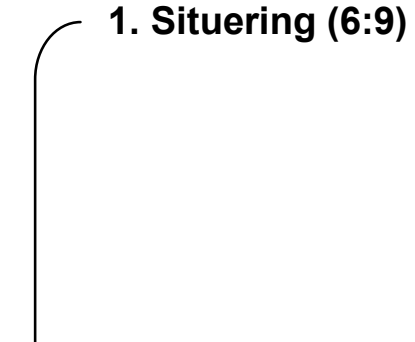

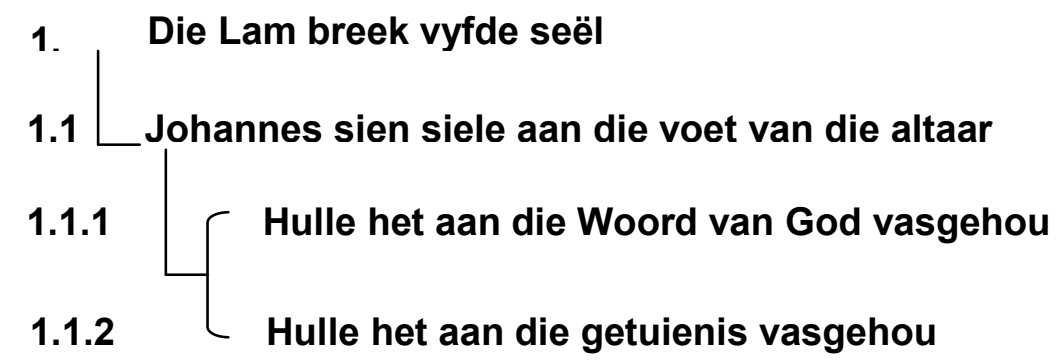

2. Hulle het hard uitgeroep:

2.1 Hoe lank nog heilige en getroue Heerser?

2.2 Wanneer voltrek U oordeel en wreek U ons dood?

3. Antwoord aan martelaars (6:11)
3.1 Elkeen ontvang lang wit klere
3.2 Aan hulle is gesê:
3.2.1 $\square$ Wag nog 'n klein rukkie totdat medegelowiges ook doodgemaak is (voltallig is)

Die gedagtegang is voor die hand liggend en logies: die situering van die oopmaak van die vyfde seël (1.1) en wat Johannes sien, bepaal die res van die gesig. Johannes sien die siele van mense wat doodgemaak is (1.2) onder die altaar, met kommentaar oor die rede waarom die siele daar beland het (1.2.1 en 1.2.2). Dit word gevolg deur die kragtige smeekroep van die siele (2) met twee duidelike vrae oor hoe lank hulle nog moet uithou (2.1) en wanneer die oordeel voltrek word (2.2). Die antwoord is duidelik (3): elkeen ontvang wit klere (3.2) en dat hulle nog 'n klein rukkie moet uithou (3.2.1). Die wanneer-vraag se antwoord is dat die getal martelaars eers voltallig moet word (3.2.1.1).

'n Aantal nuwe begrippe en terme word vir die eerste keer in Openbaring 6:9-11 gebruik. Die voorkoms van dieselfde begrippe in die res van Openbaring beantwoord reeds gedeeltelik die vraag na die betekenis en rol van Openbaring 6:9-11 in die verdere ontplooi- 
ing van die boodskap van Openbaring. Die volgende word aangetoon:

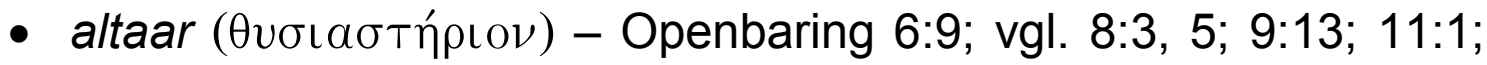
$14: 18 ; 16: 7$

- $\operatorname{siel}(\psi v \times \eta ́)$ - Openbaring 6:9; vgl. 8:9; 16:3; 18:13, 14;

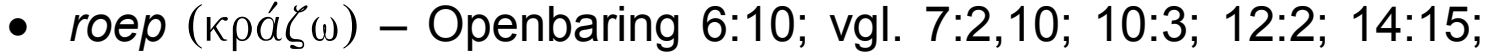
$18: 2,18,19 ; 19: 17$

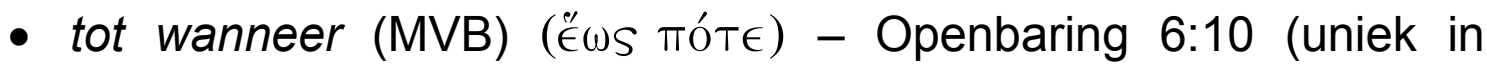
Openbaring);

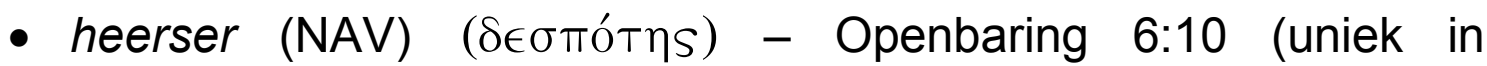
Openbaring);

- oordeel voltrek (крí $\nu \omega)$ - Openbaring 6:10; vgl. 11:18; 16:5; 18:8; 20; 19:2, 11; 20:112, 13;

- bloed (van martelaars) (тò aîi $\mu \alpha \dot{\eta} \mu \hat{\omega} \nu$ ) - Openbaring 6:10; vgl. $16: 6 ; 18: 24 ; 19: 2$;

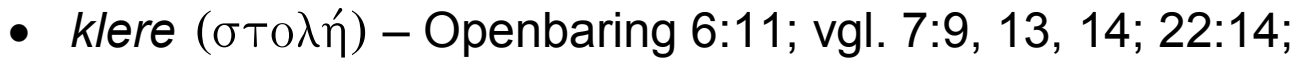

- wag/rus (

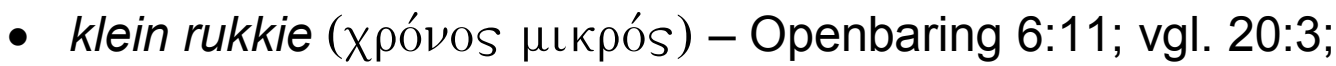

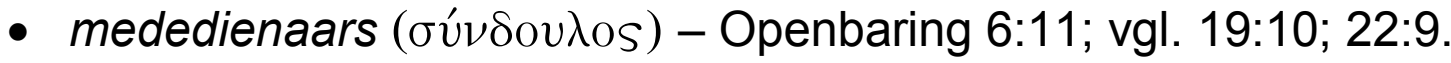

Die teologies opspraakwekkende van die "sakelys" is ongetwyfeld

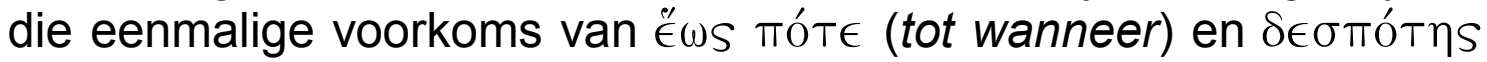
(Heerser). Dit beklemtoon die akuutheid van Christus se wederkoms en dat dit aan 'n tydspan gekoppel is. Só 'n dinamika is medebepalend vir die leefstyl van die martelaars wat nog op aarde die geloofstryd moet voer. Die terme $\dot{\alpha} \nu a \pi a v ́ \omega$ (wag/rus) en

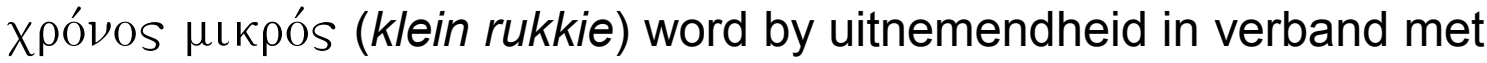
martelaarskap gebruik (vgl. Satake, 1991:312-316) Net so ook $\psi v \times \eta ́$

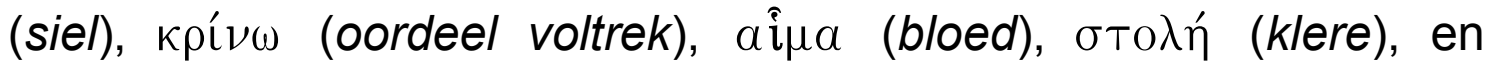

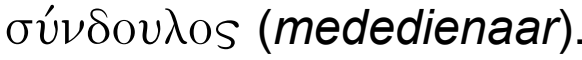




\section{Verdere eksegetiese ontleding, toegespits op navorsingsvrae}

\subsection{Die siele van doodgemaaktes onder die altaar (Op. 6:9)}

Die vertelde toneel het na die hemel verskuif. Om die hemel as ' $n$ tempel voor te stel, is geensins nuut nie (vgl. Jes. 6:1; Miga 1:2). Dit kom algemeen so voor in Openbaring (vgl. Op. 11:19; 14:17; 15:5; 16:17). Die apokaliptiese visioen volgens Esegiël 40-48 kan by wyse van interpretasie dien as primêre agtergrond van Openbaring 6:911. Meer daaroor later.

Die vraag na die identiteit van die martelaars wat doodgemaak is, vra ons aandag. Die siele is in hierdie voorkoms slegs 'n noemer vir persone wat reeds ontslaap het (vgl. Pattemore, 2004:77; Knight, 1999:69; Jacob, 1985:134).

Feuillet (1977:124) meen "siele" moet geïdentifiseer word as OuTestamentiese gelowiges. Die hoofklem val egter op Nuwe-Testamentiese martelaars wat om geloofsredes vervolg en doodgemaak is (Aune, 1998:405; Beale, 1999:390). Die redes word duidelik omskryf: dat hulle gehoorsaam gebly het aan "die Woord van God" en "die getuienis wat hulle gegee het" (Op. 6:9). Dit word ondersteun deur navorsing na die psigologiese en sosiale situasie.

Hierdie twee beskrywings ("vashou aan God se Woord" en die lewering van "getuienis") is nie net identiteitsaanduidend nie, maar dien ook as redes waarom hulle as martelaars doodgemaak is. In Openbaring 20:4 is 'n feitlik woordelikse herhaling van die "vashou aan God se Woord" en hulle "getuienis" wanneer die siele wat onthoof is, beskryf word. Moontlik word hier verwys na Christen-martelaars wat gedurende Nero se vervolgings met hulle lewens moes boet in 64 n.C. (vgl. Aune, 1998:406). Om aan die "Woord van God" vas te hou en "n getuienis" te lewer, het idiomaties kenmerkend geword van getroue Christenskap. Uit Openbaring 6:9 en 20:4, 5 kan egter nie aflei word dat alle ontslapenes noodwendig as martelaars gesterf het nie.

Die werkwoord "doodgemaak", letterlik "geslag" ( $\sigma \phi \alpha ́ \zeta \omega)$, in Openbaring 6:9 is 'n belangrike merker om te herinner aan die identifikasie met die Lam wat "geslag" is (Op. 5:6). Die bestaansgrond van gelowiges is volgens Openbaring direk gekoppel aan die "slagting" van die Lam as Verlosser en dien ook as "bestemmingsgrond" vir ' $n$ lewe na die dood. Weereens, teologie en situasie word albei deur die noodroep van die martelaars gereflekteer. 
Watter altaar is hier ter sprake? Moet gedink word aan die brandofferaltaar op grond van die bloedoffer (aldus Aune, 1998:407; Roloff, 1993:88; Swete, 1911:89), of is die reukofferaltaar ter sprake, met verwysing na die gebede van die heiliges (Beale, 1999:391; Charles, 1920:171)? Laasgenoemde moontlikheid word verkies op grond van Openbaring $8: 3,5 ; 9: 13 ; 11: 1 ; 14: 18$ en 16:7 waar ook van hierdie altaar sprake is.

In die lig van die simboliese geheelprentjie en die gerigtheid van die navorsingsvrae moet "altaar" liewer gesien word as die funksionele plek van nabyheid aan God, met albei funksies (brandoffer en reukoffer) inbegrepe, omdat die bloed van die offerdier afgedrup het van die altaar en dan aan die voet daarvan versamel het. Net so het die martelaars se lewens wat vir Christus opgeoffer is aan die "voet van die altaar" saamgevloei. Die gedagte van geoffer en gebede as aangename reukoffer, kom byeen in hierdie beeldspraak van die "altaar". Sodoende is aardse leefstyl (al gaan dit met 'n "noodroep" gepaard) verbind aan die hemelse bestemming van gelowiges wat tot die dood toe getrou gebly het.

\subsection{Die smeekbede as vraag van die martelaars (Op. 6:10)}

Die "harde stem" beklemtoon die erns van die saak. Anders as in Openbaring 7:10, word God nie geloof vir sy verlossing nie, maar is dit ' $n$ ontstelde noodroep as smeekbede dat sy regverdige oordeel moet aanbreek.

Is die smeekbede 'n wraakroep, net soos dié van Abel in Genesis 4:10 waar die Here aan Kain sê: "Die bloed van jou broer roep van die aarde af na My"? Charles (1920:175) meen die martelaars uiter 'n onchristelike wraakroep en vergelyk hierdie smeekroep met tipiese wraakkrete wat in die Joodse apokaliptiek voorkom (vgl. Ford, 1975:4; Klassen, 1966:304; en Yarbro Collins, 1979:732). Mounce (1977:158) stel dit versigtig as "a cry for theodicy not revenge"; só ook Roloff (1993:90) en Schüssler Fiorenza (1991:64). Ek meen egter Musvosvi (1993:3) is heeltemal te eensydig wanneer hy die martelaars se roep as net 'n regsgeldige smeking sien waarvolgens God 'n regsgeding teen die goddeloses moet voer. 'n Sogenaamde regsgeding belig slegs een aspek van God se oordeel oor goddeloosheid en verskraal die teologiese trefkrag van God se regverdige oordeel wat sy pad "heilshistories" moet loop, soos dit duidelik word in die in die res van die boodskap van Openbaring (Homcey, 1995:198-199). 
Ons mag nooit die moontlike Ou-Testamentiese invloed buite rekening laat nie. In Psalm 79 (LXX 78) klink ook die roep: "Hoe lank nog ...", verwysend na die tydperk voordat God teen die vyand sal optree (Ps. 79:5-6). Daardeur sal Hy aantoon dat Hy die enigste ware God is. In Sagaria 1:12 e.v. klink dieselfde vraag: "Hoe lank nog ..." voordat God Jerusalem en die stede van Juda genadig sal wees.

Die martelaars smeek God om dit eens en vir altyd duidelik te maak wie reg en wie verkeerd is. Eerstens vra die martelaars vir die voltrekking van oordeel oor diegene wat hulle benadeel en doodgemaak het. Die werkwoord oordeel ( $\kappa \rho i \nu \omega)$ is by wyse van spreke dominant bo-aan die sakelys vir die res van Openbaring se narratief, omdat God se wêreldplan met die mens veral uit twee dele bestaan, naamlik oordeel en verlossing. Die goddeloses of aardbewoners, idiomaties van die ongelowiges op aarde, word deur die seëls, trompette en bakke deur God se oordeel getref in Openbaring 6-16, asook in die finale hoofstukke 17-20, tydens die val van Babilon. Die term aardbewoners wat dertien keer in Openbaring voorkom, word met dieselfde betekenisnuanse gebruik as die meerderheid voor-

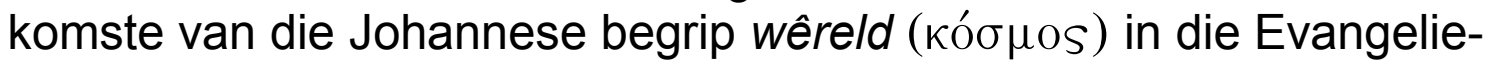
verhaal.

Die hoe lank nog ( God se mag deur die titel: Heerser ( $€ \epsilon \sigma \pi o ́ T \eta s)$, uitgebrei deur die kragtige heilig en getroue (Op. 6:10). Die titel Heerser is nie die gebruiklike om God se heerskap mee te benoem nie. Ons sou

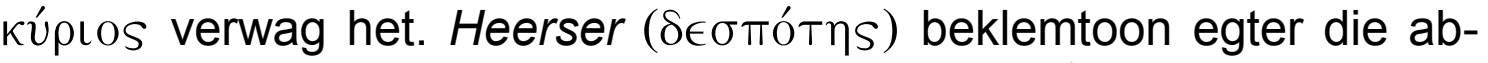
solute mag en krag van God. Alhoewel $\delta \in \sigma \pi o ́ T \eta S$ slegs hier in Openbaring aangetref word, bring dit tog die semantiese dimensie van eienaarskap sterk na vore.

God word aangeroep as die eienaar van die kosmos - en nie keiser Domitianus nie - maar ook as die eienaar van elke martelaar. Die vraag is nie of God sal oordeel nie, maar slegs wanneer. Naas

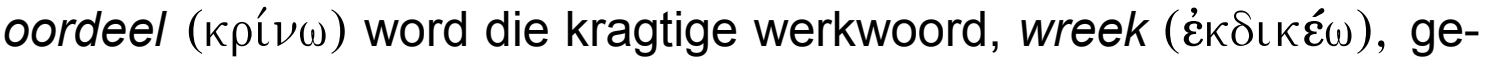
bruik om God se straf op die aardbewoners te beskryf. Dit kom nog een keer in Openbaring 19:2 voor in die danklied oor die val van Babilon: "Hy het die dood (bloed) van sy dienaars op haar gewreek". Die begrip wreek, wanneer dit van God gebruik word, is 'n menslike poging om sy goddelike regverdige oordeel mee te benoem (vgl. Klassen, 1966:304; Heil, 1993:227). Die martelaars smeek dus nie om iets nuuts nie. Hulle herinner God net aan dit wat die goddelose deur eie toedoen verdien het. Die voltrekking vind plaas volgens Openbaring 20:4-6 wanneer "die siele van die mense wat onthoof is" 
op die trone gaan sit om "as regters op te tree". Die uiteinde van God se heilige wraak, omdat Hy jaloers is oor sy eie regverdigheid en heiligheid, is dat die goddeloses in die vuurpoel gegooi is (Op. 20:14).

Volgens die Grieks in Openbaring 6:10 smeek die martelaars in hulle pleitrede dat God letterlik "ons bloed op die aardbewoners wreek" (vertaling - JADR). Dit is nie om dowe neute dat die term bloed só beklemtoon word nie. Die bloedlyn loop deur Openbaring as herinnering aan die verlossing wat die Lam bewerk het deur sy slagting (Op. 1:5; 5:9). Die uitdruklike vermelding dat die martelaars se bloed aan die voet van die altaar uitgegiet is, simbolies van hulle lewens, versterk die teologiese boodskap van die sogenaamde bloedlyn in Openbaring.

\subsection{Die tydige antwoord aan die martelaars (Op. 6:11)}

Die martelaars ontvang 'n goddelike antwoord: die Aoristus passief $\dot{\varepsilon} \delta o ́ \theta \eta ̣$ ("is gegee") en $\dot{\varepsilon} \rho \rho \dot{\varepsilon} \theta \eta$ ("is gesê") is volgens Openbaring tipies van die goddelike aktiwiteit per implikasie (vgl. Op. 6:2, 4, 8; Aune, 1998:410; Pattemore, 2004:86).

Die antwoord (Op. 6:11) is tweeledig: die martelaars ontvang "wit klere" en aan hulle word 'n boodskap gegee om aan vas te hou.

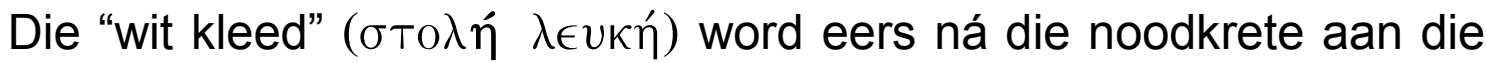
martelaars gegee en kan verskillend geïnterpreteer word. Charles (1920:184) dink aan "heavenly or spiritual bodies" en Schüssler Fiorenza (1991:64) beskou die wit kleed as 'n teken van deelname aan die bruilofsfees van die Lam. Aune (1998:410) meen weer wit klere is tipies van die hemelse wesens en gebruik "... as a polyvalent metaphor for salvation, immortality, victory and purity". Die begrip wit kleed kom vyf keer in Openbaring voor en verwys telkens na dieselfde lang kleed wat Christus volgens Openbaring 1:13 gedra het (vgl. Op. 7:9, 13, 14; 22:14).

Die triomferende Romeinse generaal het ook 'n wit kleed op sy triomftog deur die strate gedra. Suiwerheid en oorwinning word gedefinieer deur die wit kleed (Roloff, 1993:90).

Die bedoeling is dat die martelaars Christus se oorwinning sigbaar gemaak het deur hulle getuienis tot die dood toe, daarom identifiseer hulle met die wit kleed wat wit gewas is in die bloed van die Lam (vgl. Op. 7:9, 13-14). 
Die tweede deel van die antwoord aan die martelaars bevat ' $n$ op-

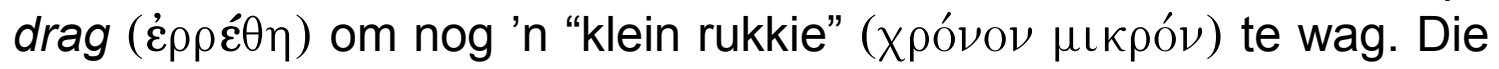
martelaars moet wag op die voltrekking van God se oordeel. Aune (1998:411) se interpretasie om 'n verband te bewys tussen die martelaars se a vatravópal en die dood, lewer nie 'n logiese en verstaanbare oplossing nie. Die martelaars is by wyse van afleiding reeds dood.

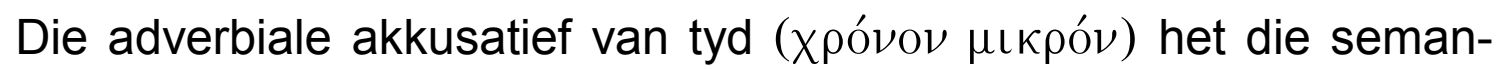
tiese funksie om die nabyheid van die wederkoms te beklemtoon (vgl. Schussler Fiorenza, 1991:49). Die dringendheid van die

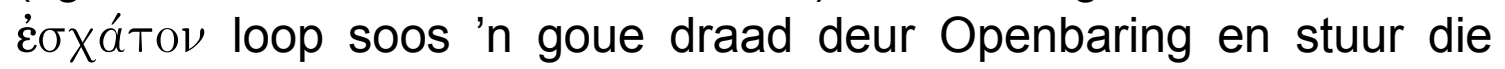
gang van gebeure soos in 'n spiraal in 'n bepaalde rigting (vgl. Op. $10: 6 ; 11: 18 ; 12: 12 ; 14: 6 ; 20: 3 ; 22: 10)$. God is besig om hierdie wêreld en sy mense voor te berei vir die finale einde.

Nog 'n faset van a vatravó $\mu$ a is die fokus op rus. Die martelaars "rus van hulle arbeid, want alles wat hulle gedoen het, volg hulle" (Op. 14:13). Hulle is deel van God se program van eindgebeure. Dit gee nog meer betekenis aan die martelaars se noodroep. Die akute vraag bly, tot wanneer duur die "kort rukkie". Die antwoord daarop is sekerlik tot wanneer die wederkoms van Christus aanbreek. Voordat dit gebeur, moet sekere dinge eers plaasvind. In hierdie geval moet die martelaars wag "totdat hulle mededienaars ... doodgemaak gaan word ... en voltallig daar is" (Op. 6:11).

Die gedagte dat daar eers ' $n$ bepaalde vol getal mense moes sterf voor die finale einde aanbreek, is tipies van apokaliptiese tekste (vgl. 2 Esra 2:40-41; 1 Henog 47:1-4; 2 Barug 21:19-23; vgl. ook Bogaert, 1980:47-68). Na die verloop van so 'n wagperiode sal God die goddeloses straf en die getroue gelowiges beloon (vgl. 1 Henog 47:1-4; 97:3-5; 102:5; 104:3).

In die antwoord dat die martelaars moet wag totdat die mededienaars doodgemaak is, is 'n kragtige bevestiging van die martelaars se identiteit. Hulle word gereken saam met die getroues aan God se Woord en die getuienis van Jesus Christus (vgl. Op. 6:9). Die res van Openbaring 6 illustreer hoe gou die finale einde sal aanbreek.

Die martelaars wat nog die hoogste prys moet betaal, word in vers

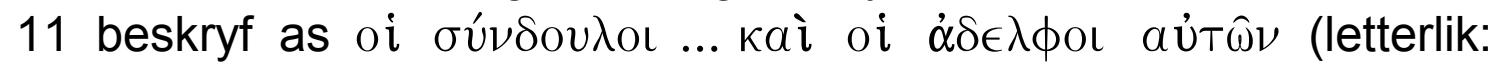
die medeslawe en hulle broers). Swete (1911:92) meen die "medeslawe" verteenwoordig al die heiliges en die "broers" die martelaars. Só 'n onderskeid lyk gedwonge. Indien die kaí ("en") 
epeksegeties geïnterpreteer word en eintlik net as 'n dubbelpunt funksioneer, is "hulle broers" slegs 'n verduidelikende uitbreiding van "die medeslawe". Die tweeledige beskrywing van die toekomstige martelaars sê iets meer oor hulle vertikale en horisontale verhoudings: hulle is God se slawe tesame met die martelaars (vertikale gesigspunt), maar ook broers en susters as jukgenote in die geloof (horisontale gesigspunt).

Die gebruik van die term $\delta o \hat{\imath} \lambda o s$ ("slaaf") is veelseggend as ons die

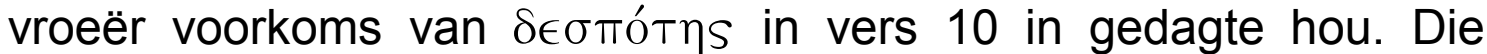
verhouding van die slaaf tot sy eienaar is in hierdie ko-teks eksegeties bepalend. Dit word verder versterk deur die fokus op oúv in $\sigma u ́ v \delta o v \lambda o l$. Dit spreek van samehorigheid en gedeelde identiteit wat in Openbaring 7:3 herhaal word as die gelowiges wat verseël moet word "die slawe van God" genoem word. Martelaarskap is ook 'n edel deel van die verhouding tussen God wat as eienaar in beheer is, en die gehoorsame "tot die dood toe slaaf" in die geloof.

In Openbaring 6:11 is die ontvangers van die goddelike antwoord nie net 'n eksklusiewe eietydse groep martelaars nie, maar dit dra ook 'n boodskap oor aan Johannes se lewende strydende "kerk" (vgl. Pattemore, 2004:90). Aan die een kant hoor God die martelaars se noodkreet en toon Hy begrip vir hulle saak wat ook sy saak is; aan die ander kant is die martelaars gewillig om te wag omdat hulle weet dat hulle in 'n vaste geloofsverhouding met God leef en dat selfs hulle dood sinvol inpas by God se wêreldplan vir sy eie. Die

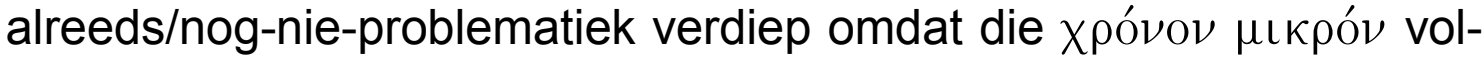
gens 'n menslike verwysingsraamwerk nie 'n lang tydspan veronderstel nie, maar vanuit God se hoek 'n lang tyd kan inhou.

\section{Teologiese neerslag}

\subsection{Oorsig van eksegetiese spiraalgang}

Die bedoeling is geensins om oor Openbaring 6:9-11 geïsoleerd te teologiseer nie, maar eerder dat die korrekte interpretasie daarvan oorgedra kan word na die res van die vertelling van Openbaring.

Slegs die opvallendste parallelle word soos volg getabuleer:

\begin{tabular}{|l|l|}
\hline $\begin{array}{l}\text { Openbaring } \\
7: 9-10,13-14\end{array}$ & wit klere, hard geroep, groot verdrukking \\
\hline $8: 3,13$ & altaar, gebede van gelowiges, aardbewoners \\
\hline $9: 13,14$ & engel, maak los die vier engele, altaar \\
\hline
\end{tabular}




\begin{tabular}{|l|l|}
\hline $11: 7,18$ & $\begin{array}{l}\text { getuienis, nasies (aardbewoners), oordeel, belo- } \\
\text { ning }\end{array}$ \\
\hline $12: 10-12$ & $\begin{array}{l}\text { stem roep hard, ons medegelowiges, boodskap, } \\
\text { min tyd, vir Hom gesterf }\end{array}$ \\
\hline $13: 7-8$ & $\begin{array}{l}\text { oorlog teen gelowiges, aardbewoners, gesag aan } \\
\text { dier }\end{array}$ \\
\hline $14: 13$ & stem roep hard, uit hemel, sterf, rus van geswoeg \\
\hline $16: 5-7$ & $\begin{array}{l}\text { oordeel, bloed van gelowiges, betroubaar en reg, } \\
\text { altaar }\end{array}$ \\
\hline $17: 6$ & bloed van gelowiges, getuig \\
\hline $18: 20,24$ & $\begin{array}{l}\text { gelowiges (martelaars), oordeel, "wraak", bloed } \\
\text { van profete }\end{array}$ \\
\hline $19: 1-2,8$ & $\begin{array}{l}\text { harde geluid, regverdig en reg, oordeel voltrek, } \\
\text { bloed van slawe gewreek, wit klere }\end{array}$ \\
\hline $20: 3-4$ & $\begin{array}{l}\text { nasies (aardbewoners), onthoofde mense, getuie- } \\
\text { nis, Woord van God }\end{array}$ \\
\hline $22: 6-9$ & $\begin{array}{l}\text { betroubaar en waar, dienaars, kom gou, } \\
\text { mededienaar, medegelowiges }\end{array}$ \\
\hline
\end{tabular}

Genoemde voorbeelde (hierbo) wek die indruk dat Openbaring 6:911 soos in 'n spiraalgang telkens inhoudelik weer aan die beurt kom. Die gedeeltes met die kragtigste ooreenkomste kom voor in die beskrywing van die oordeelsvoltrekking oor Babilon (Op. 17:1-19:10). Die martelaars se noodkreet om God se regverdige oordeelsvoltrekking vind sy klimaktiese antwoord, in negatiewe sin, in die vernietiging van Babilon en in positiewe sin, in die visioen van die nuwe Jerusalem. Die noodkreet konstitueer die martelaars se identiteit en hulle verhouding met God. Die spanning wat Openbaring 6:9-11 opgeroep het, kom tot volle ontplooiing in die finale stryd tussen die gelowiges en die bose magte (veral na Op. 11:7 tot Op. 19:10).

Die dood van God se eie (= martelaars) en hulle roep om regverdige oordeel en wraak op sonde, ontvou in die res van die boodskap van Openbaring.

\subsection{Inhoudelike parallelle tussen Openbaring 6:9-11 en 12:10-12 as voorbeeld}

Openbaring 6:9-11 stel die eksegeet in staat om deur middel van dwarsgrepe in die res van Openbaring dieper te kyk na parallelle. Vir die doel van hierdie artikel, word veral gefokus op een so 'n dwarsgreep: 'n vergelyking met Openbaring 12:10-12. 
Die volgende parallelle kom in Openbaring 12:10-12 voor: stem roep hard; ons medegelowiges; die bloed; danksy die boodskap waarvan hulle getuig het; lewens; tot die dood toe; die aarde; min tyd.

Die waarskynlikste raamwerk wat die bevredigendste agtergrond aan Johannes se vertelling in Openbaring 12:10-12 verleen, kom beslis uit die Ou Testament (vlg. Aune, 1998:667-674; Prigent, 1959:62).

Die oorwinning oor die draak met sogenaamde mitologiese parallelle is formeel deur Johannes gebruik en histories aan die oorwinning van Christus aan die kruis verbind (Op. 12:10). Die "bloed van die Lam" (Op. 12:11) is die sleutel vir interpretasie omdat dit sowel die martelaarskap as die identiteit van die martelaars in verband bring met die oorwinning as identifikasie met die Lam se oorwinning (Johns, 1998:766-769). Die verdere implikasie van oorwinning is dat die martelaars in hulle sterwe getuies is van hulle deelname aan die slagting van die Lam. Getuienis in hierdie ontwrigte wêreld, deur sonde mismaak, impliseer selfopofferende offerande, net soos in Openbaring 6:9-11.

\section{Gevolgtrekking}

Die teologiese identifisering van oorwinning met die martelaarsroep is ' $n$ belangrike eksegetiese interpretasie met teologiese trefkrag. Die noodroep van die martelaars kan nie eksegeties of teologies verbind word aan ' $n$ interpretasie van selfgelding nie. Openbaring 6:9-11 is ingebed in God se verlossingsproses.

Deur die roep van die martelaars word martelaarskap aan lyding en dood verbind en daarmee aan die "slagting" van die Lam. Dit lei daartoe dat martelaarskap aan God se oorwinning deur Jesus Christus verbind word.

Die noodroep van die martelaars moet dus eerder as 'n regverdiging van God se goeie oordeel, maar ook as 'n identiteitsroep van God se eiendom beskou word - die eiendom wat per belydenis deelneem aan God se oorwinningstog deur hierdie wêreld.

Die psigologiese effek van die martelaars se noodroep gee aan die lesers, wat in 'n hewige krisissituasie aan die einde van die eerste eeu n.C. verkeer, weer insig en hoop in hulle situasie.

Openbaring 6:9-11 kan as "sakelys" beskou word vir die res van die boodskap van Openbaring. Daarom het dit 'n belydenis van God se 
almag geword, met die versoek dat sy regverdige oordeel oor sonde sy loop deur die geskiedenis heen moet neem.

\section{Geraadpleegde bronne}

AUNE, D. 1996. Following the Lamb: discipleship in the apocalypse. (In Longenecker, R.N., ed. Patterns of discipleship in the New Testament. Grand Rapids: Eerdmans. p. 269-284.)

AUNE, D. 1998. Revelation 6-16. Dallas: Word.

BAUCKHAM, R. 1993a. The climax of prophecy: studies in the Book of Revelation. Edinburgh: Clark.

BAUCKHAM, R. 1993b. The theology of the Book of Revelation. Cambridge: Cambridge University Press.

BEALE, G.K. 1999. The Book of Revelation. Grand Rapids: Eerdmans.

BLACK, M. 1985. The Book of Enoch or 1 Enoch: a new English edition with commentary and textual notes. Leiden: Brill.

BOGAERT, P.M. 1980. Les apocalypses contemporaines de Baruch d' Esdras et de Jean. (In Lambrecht, J., ed. L'apocalypse Johannique et l'apocalyptique dans le Nouveau Testament. Gembloux: Ducelot. p. 4768.)

BORING, M.E. 1986. The theology of Revelation: "the Lord our God the Almighty reigns". Interpretation, 40:257-269.

CASEY, J.S. 1981. Exodus typology in the Book of Revelation. Louisville: Southern Baptist Theological Seminary. (Unpublished Ph.D.)

CHARLES, R.H. 1920. The Revelation of St. John. Vol. 1. Edinburgh: Clark.

COLLINS, J.J. 1977. The political perspective of the Revelation of John. Journal of biblical literature, 96:241-256.

DU RAND, J.A. 1990. Johannese perspektiewe. DI. 1. Halfweghuis: Orion.

FEUILLET, A. 1977. La moisson et la vendange de l'apocalypse: la signification chretienne de la Revelation Johannique. La nouvelle theologique, 94:113132.

FORD, J.M. 1975. The Revelation of John. New York: Doubleday.

HEIL, J.P. 1993. The fifth seal (Rev. 6:9-11) as key to the Book of Revelation. Biblica, 74:220-243.

HOMCY, S.L. 1995. To him who overcomes: a fresh look at what victory means for the believer according to the Book of Revelation. Journal of evangelical theological studies, 38:193-201.

JACOB, E. 1985. Psychē. (In Kittel, G., ed. Theological Dictionary of the New Testament. Abridged volume. Grand Rapids: Eerdmans. p. 1342-1346.)

JOHNS, L.L. 1998. The Lamb in the rhetorical program of the apocalypse of John. Society of Biblical Literature Seminar Papers, 1997:762-784.

KLASSEN, W. 1966. Vengeance in the apocalypse of John. Catholic biblical quarterly, 28:300-311.

KNIGHT, J. 1999. Revelation. Sheffield: Academic Press.

MALINA, B.J. 1995. On the genre and message of Revelation: star visions and sky journeys. Peabody: Hendrickson.

MOUNCE, R.H. 1977. The Book of Revelation. Grand Rapids: Eerdmans.

MUSVOSVI, J.N. 1993. Vengeance in the apocalypse. Berrien Springs: Andrews University Press.

OSBORNE, G.R. 2003. Revelation. Grand Rapids: Baker. 
PATTEMORE, S. 2003. Souls under the altar: relevance theory and the discourse structure of Revelation. New York: United Bible Societies.

PATTEMORE, S. 2004. The people of God in the apocalypse: discourse, structure and exegesis. Cambridge: Cambridge University Press.

PRIGENT, P. 1959. Apocalypse 12: histoire de l'exegese. Tubingen: Mohr.

PRIGENT, P. 1988. L'apocalypse de Saint Jean. 2nd ed. Genève: Labor \& Fides.

ROLOFF, J. 1993. The Revelation of John. Trans. by J.E. Alsup. Minneapolis: Fortress.

SATAKE, A. 1991. Agony and redemption according to Revelation 6. (In Breytenbach, C., Paulsen, H., Hrsg. Anfänge der Christologie. Festschrift Ferdinand Hahn zum 65. Geburtstag. Göttingen: Vandenhoeck. S. 307322.)

SCHÜSSLER FIORENZA, E. 1991. Revelation: vision of a just world. Minneapolis: Fortress.

SWETE, H.B. 1911. The apocalypse of John. London: Macmillan.

THOMPSON, L.L. 1986. A sociological analysis of tribulation in the apocalypse of John. Semeia, 36:147-174.

THOMPSON, L.L. 1990. The Book of Revelation: apocalypse and empire. New York: Oxford University Press.

YARBRO COLLINS, E. 1979. The apocalypse. Wilmington: Glazier.

\section{Kernbegrippe:}

God

Lam

martelaar

oorwinning

Openbaring 6:9-11

Openbaring 12:10-12

psigologiese effek

sosiale situasie

\section{Key concepts:}

God

Lamb

martyr

psychological effect

Revelation 6:9-11

Revelation 12:10-12

social situation

victory 
'n Noodkreet om God se regverdiging of 'n wraakroep om selfgelding? ... 